\title{
H2BC9 wt Allele
}

National Cancer Institute

\section{Source}

National Cancer Institute. H2BC9 wt Allele. NCI Thesaurus. Code C162938.

Human H2BC9 wild-type allele is located in the vicinity of $6 \mathrm{p} 22.2$ and is approximately 2 $\mathrm{kb}$ in length. This allele, which encodes histone H2B type 1-H protein, is involved in the modulation of chromatin structure. 